\title{
Desain dan Implementasi Aplikasi Video Surveillance System Berbasis Web-SIG
}

\author{
I Made Oka Widyantara, Ngurah Utami Wedanti, dan Ida Bagus Alit Swamardika
}

\begin{abstract}
Video surveillance system (VSS) is an monitoring system based-on IP-camera. VSS implemented in live streaming and serves to observe and monitor a site remotely. Typically, IPcamera in the VSS has a management software application. However, for ad hoc applications, where the user wants to manage VSS independently, application management software has become ineffective. In the IP-camera installation spread over a large area, an administrator would be difficult to describe the location of the IP-camera. In addition, monitoring an area of IPCamera will also become more difficult. By looking at some of the flaws in VSS, this paper has proposed a VSS application for easy monitoring of each IP Camera. Applications that have been proposed to integrate the concept of web-based geographical information system with the Google Maps API (Web-GIS). VSS applications built with smart features include maps ip-camera, live streaming of events, information on the info window and marker cluster. Test results showed that the application is able to display all the features built well
\end{abstract}

\section{Index Terms - Video surveillance system, IP-camera, Web-} GIS

Abstrak-Video surveillance system (VSS) merupakan sebuah sistem monitoring berbasis IP-camera. VSS diimplementasikan secara live streaming dan berfungsi untuk mengamati dan memantau suatu lokasi dari jarak jauh. Biasanya, kamera IPcamera dalam VSS memiliki aplikasi software manajemen. Akan tetapi, untuk aplikasi adhoc, dimana user ingin memanajemen VSS secara mandiri, aplikasi software manajemen tersebut menjadi tidak efektif. Pada pemasangan IP-camera yang tersebar dalam area yang luas, seorang administrator akan kesulitan untuk mendeskripsikan letak IP-camera. Disamping itu, monitoring sebuah wilayah dari IP-Camera juga akan menjadi lebih sulit. Dengan melihat beberapa kekurangan pada VSS, paper ini telah mengusulkan sebuah aplikasi VSS untuk memudahkan memonitoring setiap IP Camera. Aplikasi yang telah diusulkan memadukan konsep sistem informasi geografis berbasis web dengan Google Maps API (Web-GIS). Aplikasi VSS dibangun dengan fitur-fitur smart meliputi peta ip-camera, live streaming event, informasi pada info window dan marker cluster. Hasil pengujian menunjukan bahwa aplikasi yang dibangun mampu menampilkan semua fitur dengan baik

Kata kunci- Video surveillance system, IP-camera, WebGIS

I Made Oka Widyantara adalah dengan Lab. Sistem Telekomunikasi, Jurusan Teknik Elektro, Universitas Udayana, Denpasar, Bali (e-mail: oka.widyantara@unud.ac.id).

Ngurah Utami Wedanti adalah dengan Jurusan Teknik Elektro, Fakultas Teknik, Universitas Udayana (e-mail: utami.wedanti@ymail.com).

Ida Bagus Alit Swamardika adalah dengan Jurusan Teknik Elektro, Fakultas Teknik, Universitas Udayana (e-mail: alit_bbc@yahoo.com).

\section{PEndahuluan}

$\mathrm{T}$ INDAK kejahatan yang banyak terjadi di berbagai tempat menyebabkan keresahan bagi masyarakat sekitar. Melihat kondisi tersebut, maka perlu ditingkatkan keamanan dan pengawasan di setiap daerah. Kemajuan teknologi yang begitu pesat dapat dimanfaatkan untuk meningkatkan keamanan salah satu contohnya dengan menerapkan video surveillance system (VSS).

VSS merupakan sistem pengawasan berbasis kamera video digital yang diimplementasikan secara live streaming dan berfungsi untuk mengamati dan memantau suatu lokasi dari jarak jauh. VSS dapat berupa kamera video seperti CCTV dan IP-camera yang masing-masing telah memiliki aplikasi tersendiri.

Universitas Udayana telah membangun layanan VSS berbasis IP-camera, dengan memasang perangkat IP-camera dilokasi-lokasi strategsi kampus. Namun banyaknya jumlah perangkat IP Camera yang ada serta terbatasnya fungsi aplikasi IP Camera, menyebabkan sistem VSS di Universitas Udayana menjadi tidak efisien untuk digunakan. Seorang operator hanya memonitor tampilan tanpa mengetahui dimana lokasi kamera tersebut terpasang.

Terkait dengan VSS banyak penelitian telah dilakukan dengan focus pada peningkatan kinerja aplikasi. Kieran dkk (2011)[1] mengusulkan sebuah skema VSS dengan kemampuan penjejakan obyek dari multiple kamera. Skema ini memudahkan operator untuk mereview tampilan video berdasarkan kejadian. Munculnya teknik pengolahan sinyal cerdas seperti data mining, pengenalan pola dan computer vision telah mengilhami lahirnya konsep intelligent video surveillance system, dimana penjejakan obyek dalam video dapat diterapkan pada mengklasifikasi kejadian-kejadian normal dan abnormal berdasarkan ekstrski fitur obyek[2][3]. Realisasi aplikasi VSS berbasis Web juga diusulkan oleh beberapa peneliti dengan tujuan untuk sistem monitoring jarak jauh, seperti untuk sistem monitoring home care[4][5].

Didasarkan pada tujuan untuk memudah manajemen layanan monitoring video di Universitas Udayana, paper ini mengajukan sebuah model VSS dimana visualisasi tampilan video dapat diakses pada sebuah peta spasial dan berbasis Web. Metode yang digunakan adalah memanfaatkan sistem informasi geografis berbasis web yaitu Google Maps API (Web-SIG) ke dalam aplikasi VSS. Sistem informasi geografis (SIG) digunakan karena, SIG memiliki fitur-fitur yang mendukung aplikasi VSS seperti menampilkan pemetaan 
wilayah Universitas Udayana beserta informasi didalamnya, marker cluster, dapat melakukan pengecekan perangkat IP Camera yang sedang berada pada posisi hidup (on) atau mati (off), dan masih banyak fitur pintar lainnya. Maka, kontribusi utama dari paper ini adalah realisasi aplikasi VSS dengan mengkombinasikan teknologi Web dan SIG untuk visualisasi stream video dan posisi penempatan IP-camera.

Selanjutnya, paper ini diorganisasikan sebagai berikut; bab I memaparkan tentang latar belakang disertai tujuan pengembangan VSS berbasis Web-GIS, bab II memaparkan tentang konsep dasar VSS, bab III memaparkan tentang realisasi VSS berbasis Web-SIG, bab IV memaparkan tentang hasil dan pembahasan aplikasi VSS yang telah dibangun, dan bab V adalah kesimpulan dari paper ini.

\section{VIDEO SURVEILLANCE SYSTEM (VSS)}

VSS Video surveillance system adalah suatu aplikasi live streaming dengan menggunakan beberapa kamera pada suatu tempat yang dapat dimonitoring dengan cara streaming. Video surveillance system tersebut dapat digunakan untuk memantau suatu wilayah dari jarak yang jauh seperti lalu lintas internet dan telepon [6]. Gambar 1 menunjukan skema VSS video surveillance.

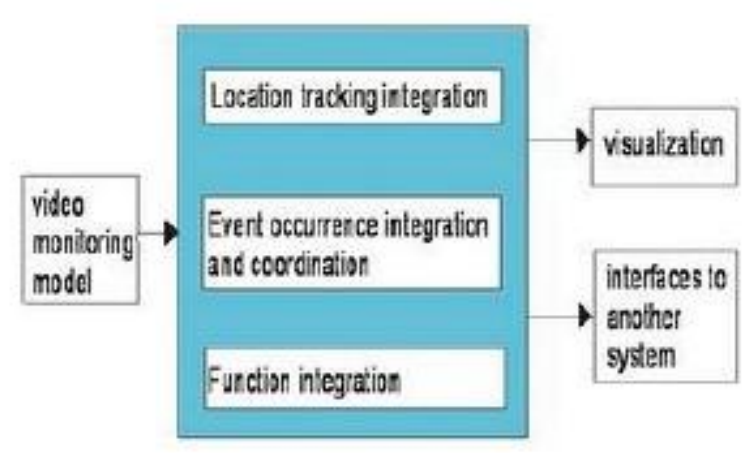

Gambar 1. Skema Video surveillance

Bagian location tracking integration merupakan gerakan pendeteksian yang mengikuti jalan pekerjaan suatu objek. Bagian event occurrence integration and coordination adalah mengenai korelasi aktivitas untuk keputusan akhir, function integration dan deteksi untuk IDS, VoIP, dan menggabungkan dengan WLAN yang ada untuk sistem keamanan.

Untuk merealisasikan aplikasi VSS berbasis Web-SIG, beberapa konsep yang harus dipahami dipaparkan sebagai berikut.

\section{A. IP Camera}

IP Camera merupakan perkembangan dari kamera CCTV yang telah mempunyai IP Address tersendiri dari masingmasing IP Camera, sehingga dapat memilih IP Camera yang ingin dilihat. IP Camera tersebut telah memiliki akses web service yang tertanam pada IP sehingga memungkinkan IP Camera dapat diakses melalui koneksi internet [7]. Seperti ditunjukan pada Gambar 2, sistem IP Camera dirancang secara digital agar gambar dan suara yang masuk dan terekam pada perangkat IP Camera sudah dalam bentuk format digital. Data tersebut nantinya dapat dikirimkan melalui jaringan komputer atau internet [8].

. IP Camera memiliki fitur-fitur diantaranya yaitu :

- 2 way audio, fitur ini memungkinkan user untuk berkomunikasi dengan apa yang mereka lihat.

- LED lighting, pada fitur ini menggunakan night vision yang berguna untuk memberikan user melihat daerah yang kurang cahaya atau gelap.

- Streaming, beberapa IP Camera yang mempunyai resolusi 640x480 dan mempunyai kemampuan merekam 30 frame perdetik dapat melihat kamera secara streaming.

- Jaringan nirkabel, konfigurasi awal dilakukan melalui router, akan tetapi setelah IP Camera terinstall, dapat digunakan menggunakan jaringan nirkabel[8].

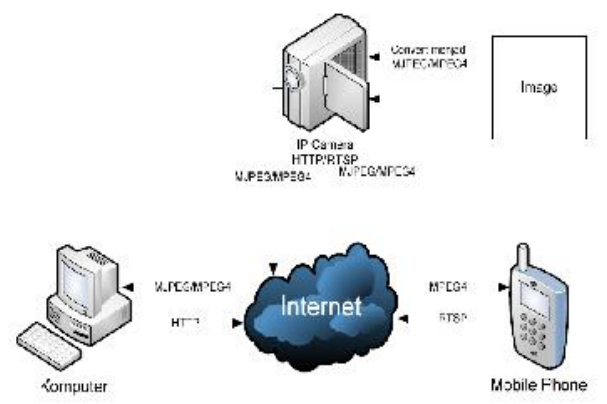

Gambar 2. Kerangka kerja sistem IP-camera

Pada Kampus Universitas Udayana telah terpasang teknologi IP Camera yang digunakan sebagai penunjang sistem sekuriti pada area kampus. Jenis IP Camera yang digunakan adalah merk Sony serta software pendukung Sony Realshot Manager dengan server yang digunakan adalah Sony IPELA NSR 1200. Penggunaan server Sony IPELA NSR 1200 dipilih dikarenakan memiliki kualitas dari merek NSR-1000 Series ini memiliki kemampuan hybrid, dan mendukung "both legacy analogue". Terdapat sekitar 32 kamera pada kampus Sudirman yang terhubung pada sistem jaringan

\section{B. Sistem Informasi Geografis (SIG)}

Sistem informasi geografis adalah salah satu sistem informasi yang menggabungkan antara unsur peta (geografis) dan informasi tentang peta tersebut (atribut). Sistem ini dirancang untuk mendapatkan, mengolah memanipulasi, analisa, memperagakan dan menampilkan data spatial untuk menyelesaikan perencanaan, mengolah dan meneliti permasalahan [9]. Gambar 3 menunjukkan struktur komponen pembentuk sistem informasi geografis.

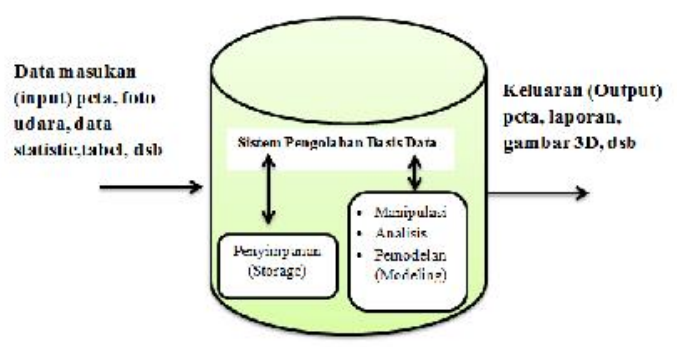

Gambar 3. Struktur komponen pembentuk sistem informasi geografis. 
Pemodelan data pada sistem informasi geografis berupa data digital yang berformat data raster dan data vektor. Data vektor menyimpan data digital dalam bentuk rangkaian koordinat $(\mathrm{x}, \mathrm{y})$, sedangkan data raster menyatakan data grafis dalam bentuk rangkaian bujur sangkar yang membentuk gridscells [10].

\section{MYSQL}

MySQL adalah user database yang menggunakan bahasa Structured Query Language (SQL). MySQL dalam operasi client-server melibatkan server daemon MySQL disisi server dan berbagai macam program serta library yang berjalan disisi client. MySQL memiliki kemampuan untuk menangani data yang cukup besar. SQL adalah bahasa standar yang digunakan untuk mengakses database server. Bahasa ini pada awalnya dikembangkan oleh IBM. Namun telah diadopsi dan digunakan sebagai standar industri. Dengan menggunakan bahasa SQL, proses akses database menjadi lebih user-friendly [11].

\section{REALISASI VSS BERBASIS WEB-SIG}

Realisasi VSS untuk meningkatkan kualitas sistem pengawasan video di universitas Udayana mengacu pada model berbasis web-GIS dari [12][13]. Dalam pemodelan aplikasi VSS, data yang diperlukan oleh sistem ditransformasikan ke dalam bentuk arsitektur program, yang nantinya diimplementasikan dalam tahap pembuatan dan pengembangan sistem.

\section{A. Gambaran Umum Sistem}

Aplikasi VSS dengan memanfaatkan sistem informasi geografis berbasis web yang dibuat disajikan dalam bentuk UML (Unified Modeling Language) yang merupakan bahasa pemodelan yang menggunakan konsep orientasi object untuk menggambarkan sebuah sistem. Gambar 4 menunjukan gambaran umum sistem aplikasi.

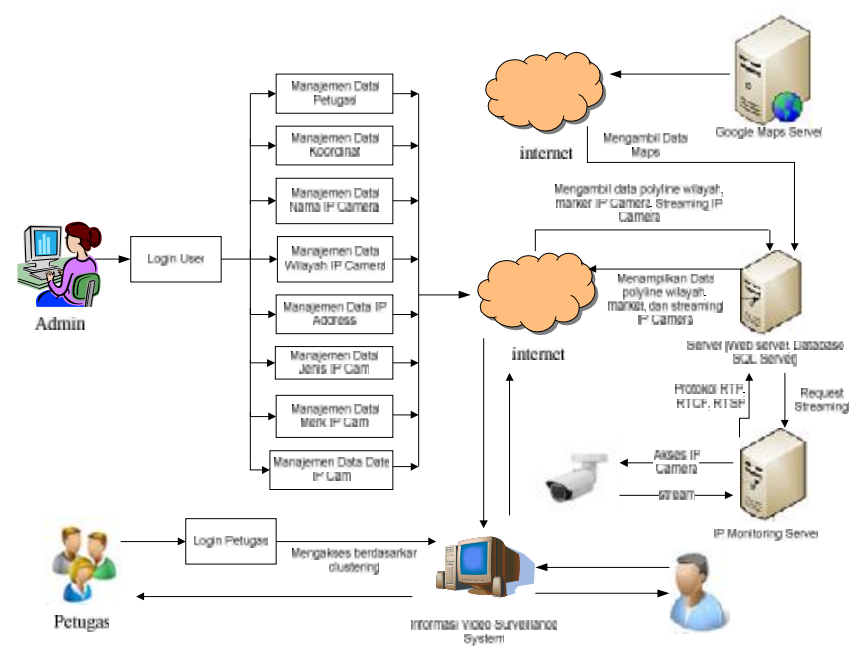

Gambar 4. Gambaran Umum Sistem

Pada gambaran umum sistem yang ditunjukkan pada Gambar 5, terdapat 2 aktor yang berhubungan dengan sistem, yaitu pegawai atau petugas admin, dan public user. Data informasi tentang peta yang telah diiputkan diolah pada database server, kemudian IP address yang diinputkan meminta live stream IP ke server streaming yang ada, dan server streaming melakukan pengaksesan ip address. Proses akses yang telah dilakukan ke IP-camera kemudian menghasilkan file audio dan video yang di stream berupa sebuah buffer, file yang telah tersimpan kemudian dikirimkan dengan bantuan protokol streaming yaitu RTP, RTCP, RTSP, dan HTTP. Setelah melalui protocol streaming, maka hasil stream dapat melakukan embed data dan kemudian ditampilkan pada Sistem Informasi Geografis. Selanjutnya pengguna akan dapat melihat pemetaan streaming IP Camera.

\section{B. Perancangan Data Flow Diagram (DFD}

Perencanaan data flow diagram sangat penting dilakukan karena mempermudah proses pengerjaan dan pemahaman hubungan kinerja antar entitas yang terlibat. Perancangan DFD terdiri dari perancangan Diagram Konteks, Diagram Jenjang (Hierarchy Chart), DFD Level 0 dan DFD Level 1. Pada Gambar 6 menunjukkan Diagram konteks VSS..

Pada diagram konteks, sistem ini memiliki dua eksternal entitas, yaitu sebagai user dan pengguna. User merupakan salah satu admin yang bertugas untuk menginputkan dan mengolah data-data yang telah diperoleh agar dapat ditampilkan pada video surveillance system, sedangkan pengguna mendapatkan informasi geografis di dalam sistem berupa marker lokasi IP Camera, dan streaming IP Camera. Diagram jenjang VSS ditunjukkan pada Gambar 5

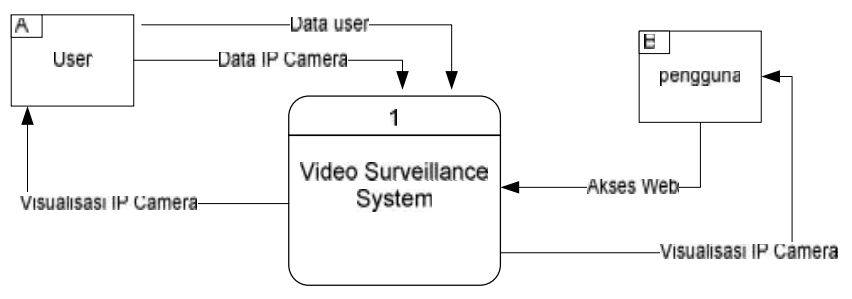

Gambar 5. Diagram konteks Video Surveillance System

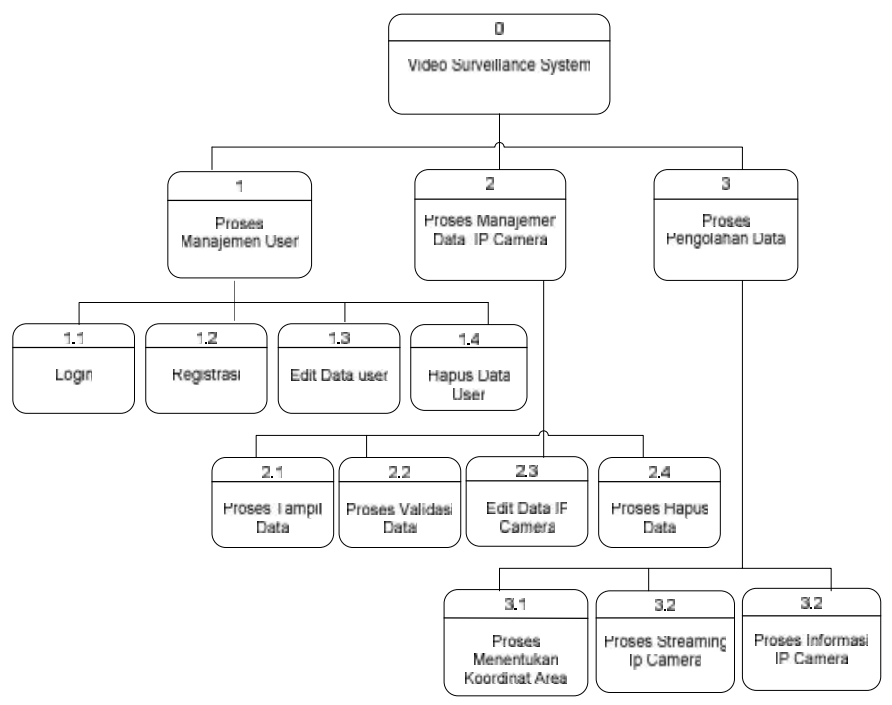

Gambar 6. Jenjang (hierarchy chart) Video Surveillance System 


\section{Perancangan Database VSS}

Perancangan database menjelaskan tentang struktur penyimpanan data pada database yang digunakan untuk menyimpan data aplikasi video surveillance system berbasis web. Seperti ditunjukan pada Gambar 7, database aplikasi VSS terdiri dari 4 tabel yaitu tb_user, tb_cluster, tb_makers, dan tb_akses yang masing-masing telah mempunyai relasi antar table.

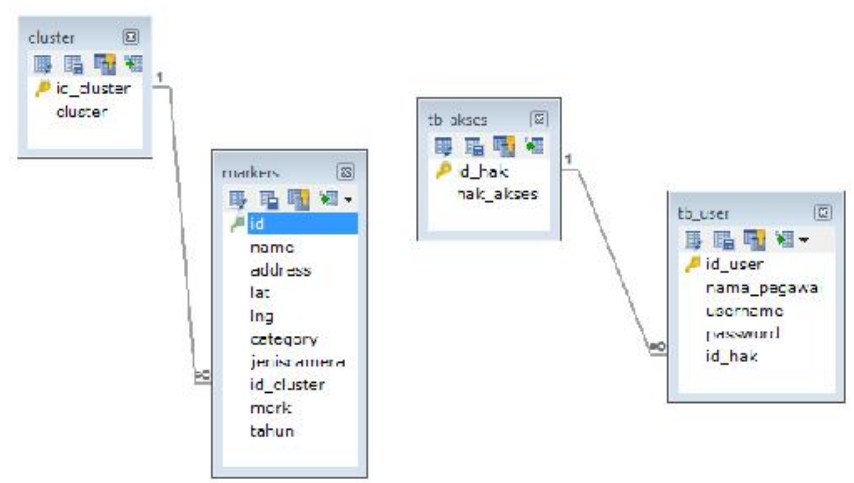

Gambar 7. Diagram Antar Tabel

\section{Perancangan Antar Muka}

Perancangan antarmuka merupakan tampilan atau display dari suatu program, yang berinterkasi secara langsung oleh pengguna. Antarmuka dirancang secara sederhana agar pengguna tidak mengalami kesulitan dalam menggunakan sistem tersebut. Gambar 8 merupakan salah satu antarmuka dari aplikasi video surveillance system, yang dirancang agar sesuai dengan fungsi-fungsi yang diinginkan dalam aplikasi ini.

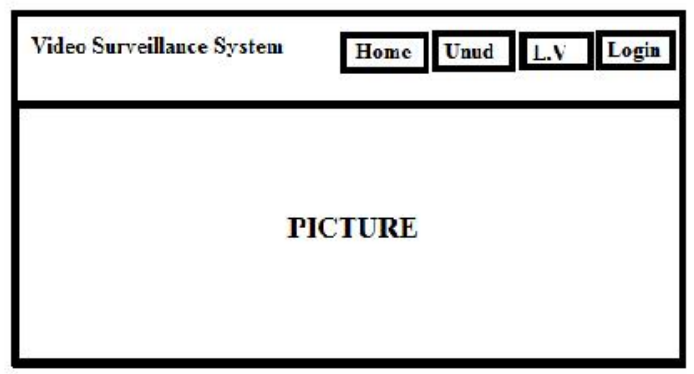

(a)

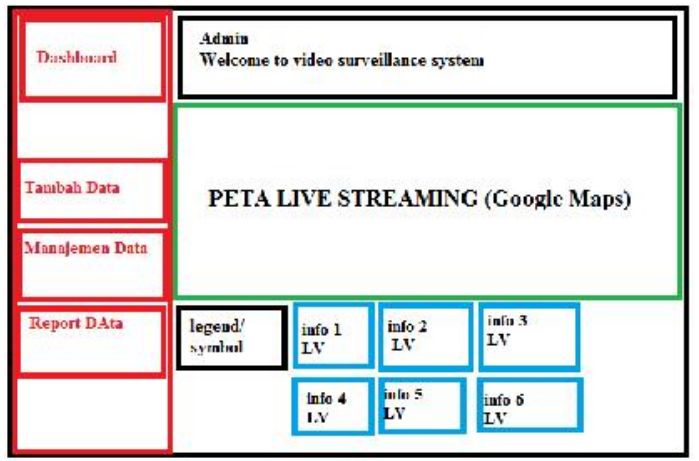

(b)

Gambar 8. Rancangan Antarmuka VSS, (a) Halaman depan, (b) Halaman Admin

\section{PEMBAHASAN}

\section{A. Pengujian Integrasi Google Maps Pada Aplikasi}

Pada tahap ini, dilakukan analisis terhadap integrasi Google Maps dengan aplikasi berbasis Web. Google Maps Api tidak hanya dapat digunakan pada aplikasi berbasis Web saja, namun Google Maps Api dapat pula digunakan pada ios maupun android. Agar Google Maps dapat diintegrasikan pada aplikasi berbasis Web, pada tag html library Google Maps harus diimpor terlebih dahulu melalui tag script. Gambar 9 menunjukkan tampilan peta Google Maps pada aplikasi

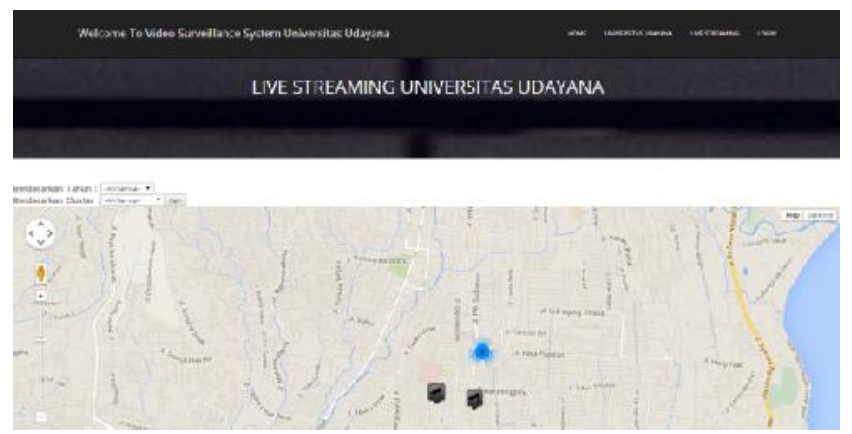

Gambar 9. Tampilan Peta Google Maps Pada Aplikasi

Setelah proses integrasi Google Maps pada aplikasi berhasil, maka peta Google Maps dapat dijadikan sebagai komponen peta digital yang digunakan untuk memetakan IP Camera pada aplikasi VSS

\section{B. Pengujian IP Address IP Camera Pada SIG}

Pada tahap ini dilakukan analisis terhadap IP Address dari masing-masing IP Camera di wilayah Universitas Udayana agar dapat diintegrasikan ke dalam peta Google Maps Api. Peta Google Maps nantinya akan dapat menampilkan markermarker dari IP Camera di setiap titik lokasi yang diinputkan pada aplikasi. IP Address yang diinputkan pada aplikasi sistem informasi geografis yaitu peta Google Maps, akan dapat menampilkan hasil live streaming dari masing-masing IP Camera. Serta dapat melakukan proses pengecekan IP Address dari masing-masing perangkat IP Camera. Proses tersebut akan menunjukkan posisi IP Camera dalam kondisi off dan on. Gambar 10 menunjukkan tampilan live streaming

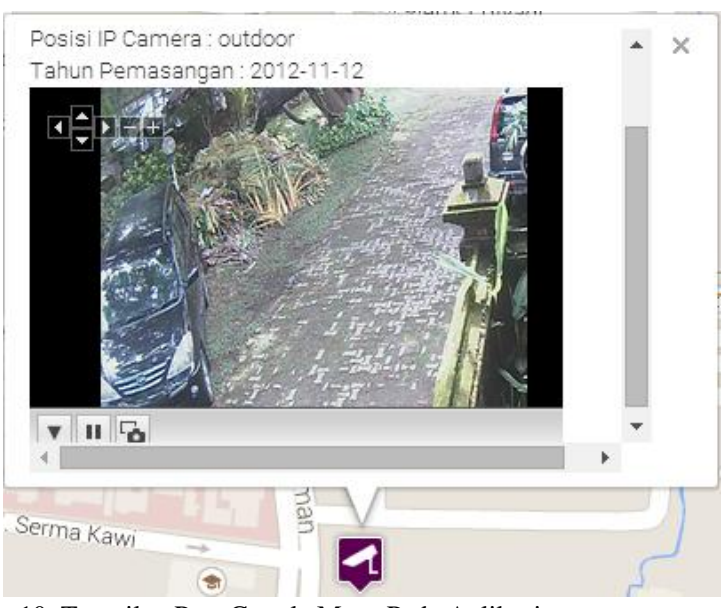

Gambar 10. Tampilan Peta Google Maps Pada Aplikasi 
Setiap IP Camera memiliki IP Address yang berbeda-beda sesuai dengan posisinya. Agar IP Address dapat diakses pada aplikasi, maka dibuatkan suatu file php yang digunakan untuk memanggil tampilan live streaming

\section{Pengujian Tampilan Multi Display Live Streaming}

Video surveillance system terdiri dari beberapa IP Camera yang membutuhkan beberapa tampilan multi display. Tampilan ini dapat melihat secara bersamaan live streaming dari IP Camera yang diinginkan. Pada aplikasi ini tampilan multi display telah dibatasi dengan 6 tampilan kotak dialog sebagai tempat penampil live streaming, masing-masing kotak akan terisi sesuai dengan urutan saat marker di klik. Gambar 11 menunjukkan multi display VSS

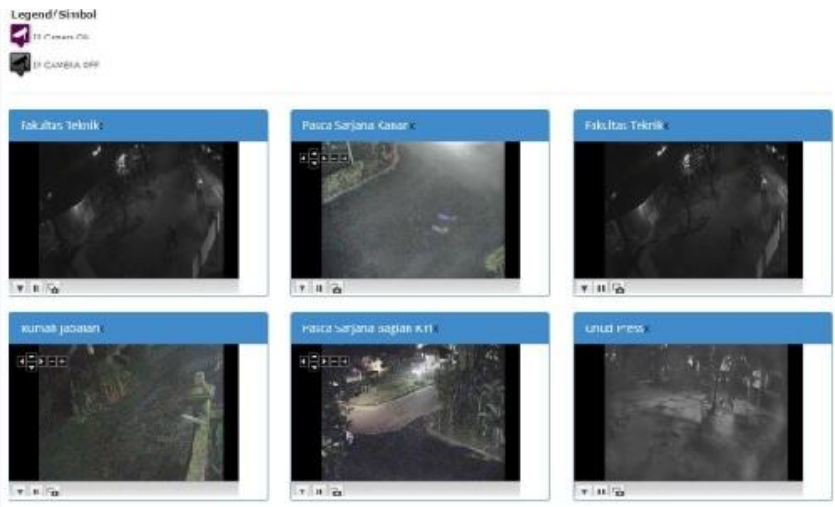

Gambar 11. Tampilan Multi Display VSS

\section{Pengujian Informasi Pemetaan Live Streaming}

Informasi pemetaan live streaming IP Camera pada Google Maps akan ditampilkan pada kotak dialog info window. Informasi tersebut terdiri dari informasi lokasi IP Camera, alamat IP Address, tanggal pemasangan, merk IP Camera, dan posisi pemasangan IP Camera. Pengujian informasi pemetaan dilakukan dengan melakukan uji coba aplikasi kepada public user, dan administrator untuk menginputkan data-data informasi IP Camera. Data informasi IP Camera yang telah diinputkan, apabila telah terinput dan dapat ditampilkan oleh info window, maka pengujian informasi live streaming telah berhasil. Pada Gambar 12 merupakan tampilan info window.

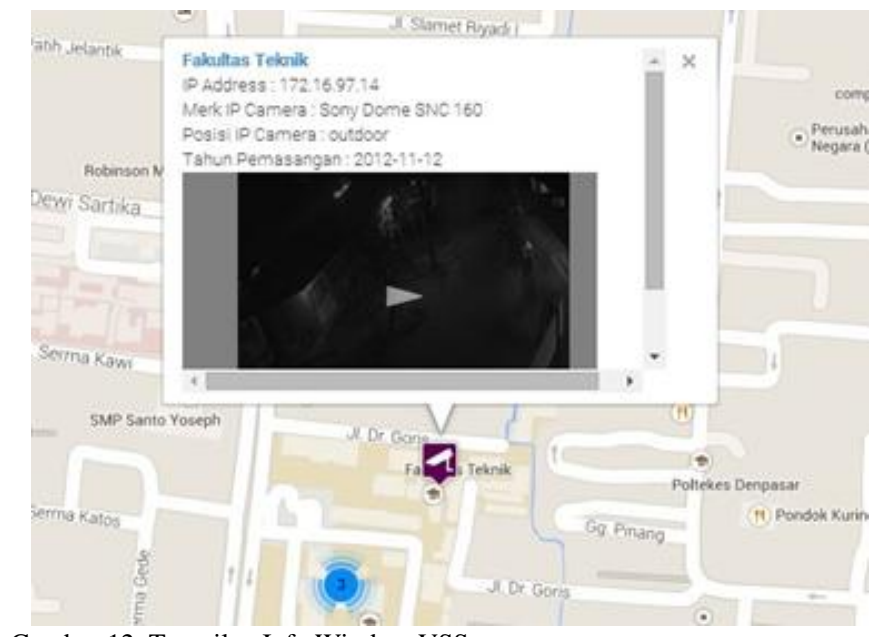

Gambar 12. Tampilan Info Window VSS

\section{E. Pengujian Clustering Marker IP Camera}

Proses cluster digunakan untuk mengelompokkan markermarker yang memiliki wilayah yang berdekatan. Hal ini bertujuan saat terdapat banyak marker pada peta, semua marker tersebut terkelompok sehingga tidak terlihat tidak beraturan pada peta. Proses pengelompokkan marker dapat dilakukan dengan menggunakan javascript. Javascript pengelompokkan marker dapat didownload di beberapa Website dengan nama markerclusterer_packed.js. Nantinya file java script tersebut akan dipanggil pada source code aplikasi dengan memasukkan ke dalam tag html file php. Pada Gambar 13 merupakan tampilan clustering IP Camera

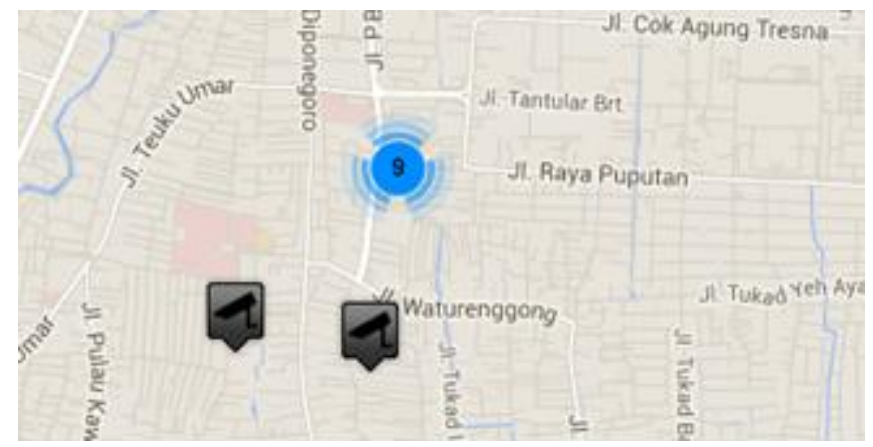

Gambar 11. Tampilan Multi Display VSS

\section{KESIMPULAN}

Paper ini telah memaparkan model VSS berbasis Web-SIG untuk meningkatkan efisiensi visualiasi streaming video IP Camera. Model VSS yang diusulkan menambahkan fitur-fitur layanan seperti marker cluster atau grouping marker, kemudian fitur untuk menampilkan live streaming IP Camera dan yang terakhir adalah fitur geometry untuk memperoleh koordinat pemetaan IP Camera. Hasil uji coba yang dilakukan dengan menggunakan analisa usability software, yaitu tahap analisa terhadap tingkat kemudahan, serta pemahaman pengguna baik itu pengguna umum yaitu masyarakat ataupun admin, dalam menggunakan aplikasi yang telah dibuat, menunjukan bahwa fitur-fitur dalam Google Map API tersebut dapat berjalan dengan baik pada aplikasi yang berjalan di Web

\section{DAFTAR PUSTAKA}

[1] D. Kieran, J. Weir, W. Yan," A Framework For An Event Driven Video Surveillance System", Journal Of Multimedia, Vol. 6, No. 1, 2011, hal. 3-13

[2] X. Wang," Intelligent multi-camera video surveillance: A review", Pattern Recognition Letters 34, 2013, hal. 3-19

[3] M. G. Kim, H. M. Moon, Y. Chung, dan S. B. Pan," A Survey and Proposed Framework on the Soft Biometrics Technique for Human Identification in Intelligent Video Surveillance System", Journal of Biomedicine and Biotechnology Volume 2012, hal. 1- 7

[4] B. Yuan dan J. Herbert," Web-based Real-time Remote Monitoring for Pervasive Healthcare", IEEE International Conference on Pervasive Computing and Communications Workshops (PERCOM Workshops), 2011, hal. 625-629

[5] B. R. Chen, S. Patel, T. Buckley, R. Rednic, D. J. McClure, L. Shih, D. Tarsy, M. Welsh, dan P. Bonato," A Web-Based System for Home Monitoring of Patients With Parkinson's Disease Using Wearable Sensors", IEEE Transactions On Biomedical Engineering, Vol. 58, No. 3, 2011, hal. 831-836

[6] I. Irawan, "Pengenalan Implementasi Video surveillance system Di Segala Bidang”, 2010. Diakses tanggal 30 September 2014 
[7] I, Greg, "Whats In An IP Camera", 2009. http://www.networkwebcams.com/ip-camera-learning-center/. Diakses tanggal 21 September 2014.

[8] R. Arfiansyah,"Aplikasi Android Untuk Kontrol Dan Monitoring Ruangan Menggunakan IP Camera", Journal Teknik Informatika, Vol 1, No. 81, 2012.

[9] S. M. Putra, Handoko, R. Mandasari, B. P. Bestari,"Analisis dan Perancangan Aplikasi Monitoring IP Camera Menggunakan Protokol HTTP Pada Mobile Phone", Seminar Nasional Aplikasi Teknologi Informasi, 2010, hal. F11-F17

[10] N. Bafdal,’Buku Ajar Sistem Informasi Geografis", 2011

[11] P.T. Tranggono, "Simulasi Sistem Informasi Kondisi Lalu Lintas Dengan Kamera CCTV Berbasis GIS", Stikom Surabaya. http://digilibstikom.edu. Diakses tanggal 20 September 2014.

[12] P. Permana, "Pemantauan Kondisi Lalu Lintas Menggunakan Smart Visualisation System", Bidang Studi Teknik Sistem Komputer ITS Surabaya, 2009. Diakses tanggal 28 Agustus 2014.

[13] A.R. Trisnawati, "Pemantauan Sistem Informasi Bangunan Cagar Budaya Berbasis Web Gis (Studi kasus : Kota Surabaya)", P.S Teknik Geomatika, ITS Surabaya, 2011. Diakses tanggal 20 September 2014.

[14] E. Budiyanto, "Sistem Informasi Geografis Menggunakan Arc View GIS. Yogyakarta : ANDI, 2005

[15] A.Sodiq,"Tutorial Dasar Pemrograman Google Maps Api”, 2012. Diakses tanggal 28 Agustus 2014.

[16] http://maps.google.com Diakses tanggal 28 Agustus 2014.

[17] K. Peranginangin, "Aplikasi Web Dengan PHP dan MySQL", Yogyakarta: ANDI, 2006. 